\title{
Effect of water infiltration on the mechanical behaviour of unsaturated soil
}

\author{
Ali Murtaza Rasool $^{1,2, *}$ and Jiro Kuwano ${ }^{1}$ \\ ${ }^{1}$ Departmen of Civil \& Environmental Engineering, Saitama University, Japan \\ ${ }^{2}$ National Engineering Services Pakistan (NESPAK), Lahore, Pakistan
}

\begin{abstract}
Natural slopes and embankments are generally unsaturated in nature with negative pore water pressure adding to the shear strength and hence the stability of the slopes. During the event of rainfall, pore water pressure becomes less negative or even positive as a result the shear strength of soil decreases and failure occur. Therefore, the strength and deformation characteristics for unsaturated soil become important when analysing the stability of these types of slopes. In this study, a triaxial test apparatus was used to study the effect of water infiltration on the mechanical behaviour of unsaturated soil. The test results show that water infiltration decreased with increase in net confining stress and the stress paths were independent of the matric suction, the net confining stress and the shearing conditions for the present experimental study.
\end{abstract}

\section{Introduction}

In many parts of the world, slope failures normally occur in shallow vadose zones having a profound ground water table. Most of the time during the year, such slopes remain in an unsaturated state with negative pore water pressure adding to the shear strength and hence the stability of the slope. During the event of the rainfall pore water pressure becomes less negative or even positive due to infiltration of rainwater into the slope surface, as a result, matric suction reduces. Thereby, decreasing the shear strength of soil which ultimately leads to failure of slope [1]. The strength and deformation characteristics for unsaturated soil become important when analysing the stability of these types of slopes. Bishop (1960) [2] and Fredlund et al. (1978) [3] studied the mechanical behaviour of unsaturated soil by taking matric suction for an evaluation of the strength parameter. It is also important to understand the characteristics of pore pressure changes in soils due to water infiltration in order to predict the extent of reduction in shear strength under certain rainfall conditions [4]. Normally, when soil on the surface layer of a slope is subjected to water infiltration under constant shear stress, there will be some reduction in strength. The water infiltration can lower the shear strength to a close value to the average shear stress along the potential failure surface.

This study investigated the effect of water infiltration on the mechanical behaviour of unsaturated soil. The water was infiltrated into unsaturated soil specimen and sheared under drained and undrained conditions for pore water pressure. The effect of water infiltration was studied on the void ratio, the degree of saturation, matric suction and deviatoric stress. Finally, the effect of stress paths on failure state and failure line was studied and discussed.

\section{Testing programme}

In this part, the physical properties of soil and specimen properties will be discussed.

\subsection{Physical properties of soil}

DL Clay is the commercial name of the soil used in this study, it is a fine material without plasticity. The appearance of freshly and freely deposited DL clay looks yellowish brown. Dried and powdered DL clay consists of Kaolinite and silica. Kaolinite and silica stones are used as agricultural chemicals. According to the Japanese Geotechnical Society (JGS), it is classified as having Medium-Low compressibility (ML) and is composed of $90 \%$ silt and $10 \%$ clay which show that it is larger in grain size than average clay. Table 1 shows the physical properties of this soil.

Table 1. Physical properties of DL clay.

\begin{tabular}{|c|c|c|}
\hline Properties & Unit & Value \\
\hline Density of soil particle, $\rho_{\mathrm{s}}$ & $\mathrm{g} / \mathrm{cm}^{3}$ & 2.654 \\
\hline Consistency & - & $\mathrm{NP}$ \\
\hline Maximum dry density, $\rho_{\max }$ & $\mathrm{g} / \mathrm{cm}^{3}$ & 1.538 \\
\hline Optimum water content & $\%$ & 20 \\
\hline
\end{tabular}

\subsection{Specimen properties}

The specimens used in the present study were prepared using the static compaction method. Prior to performing the compaction, dry DL clay, with a soil particle density of $2.654 \mathrm{~g} / \mathrm{cm}^{3}$, was mixed well with water to make up

\footnotetext{
* Corresponding author: ali_eng@hotmail.com
} 
$20 \%$ of the water content. Then, the mixed wet DL clay was compacted statically in a cylindrical mould, $5 \mathrm{~cm}$ in diameter, to obtain a uniform density throughout the length of the specimens. The specimens were compacted in 5 layers, each $2 \mathrm{~cm}$ thick [5]. The low energy from the static compaction can produce a uniform density that prevents the development of a weaker region in the specimen [6]. The pre-consolidation pressure on a specimen during preparation was approximately $300 \mathrm{kPa}$. The void ratio of the specimens was around 1.1 and the initial degree of saturation was $47.5 \%$. The measured initial matric suction was $19 \sim 20 \mathrm{kPa}$ for all specimens, which means that the preparation procedure was always followed carefully in order to maintain a suction state of approximately $20 \mathrm{kPa}$. All the specimens had a dry density of $1.3 \mathrm{~g} / \mathrm{cm}^{3}$ and a degree of compaction $80 \%$.

\subsection{Soil water characteristic curve (SWCC)}

The relationship between matric suction and water content is generally termed as the soil-water characteristic curve (SWCC). Such curves are usually measured in the laboratory through pressure plate tests or $\mathrm{pF}$ tests, though the current experimental setup was used to establish the SWCC relation. Several soil specimens with varying water content were prepared and placed on top of a membrane filter and values of initial suction were measured, the same technique to draw SWCC was also used by Farooq et al. (2004) [7]. Figure 1 shows the expected results i.e. the matric suction decreases as the degree of saturation increases.

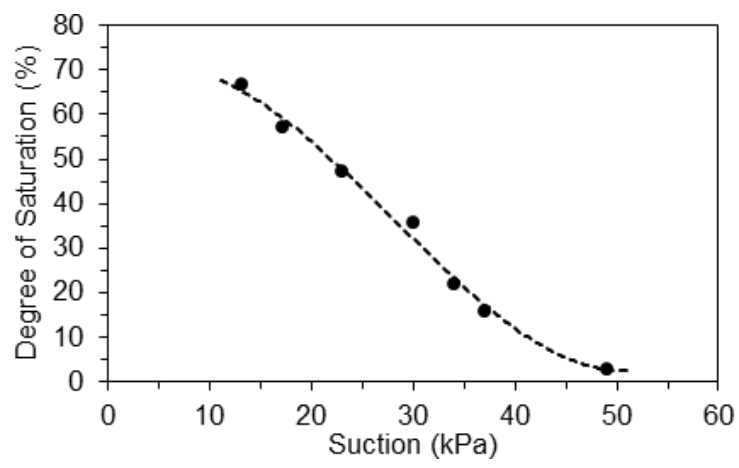

Fig. 1. Variation of matric suction with degree of saturation

\section{Test setup, procedure and programme}

In this part, main parts of the triaxial test apparatus, test procedure and program will be discussed.

\subsection{Experimental setup}

The test apparatus used in this study consists of a doublewalled triaxial cell, an axial loading device, pore-air, pore water and cell pressure transducers as shown in Figure 2(a). The salient feature of this triaxial apparatus is that both pore air and water pressures can be measured separately. The pore air pressure transducer is installed in the top cap and is connected to the air regulator in order to give a continuous supply of air throughout the test. The change in volume of the specimen during the triaxial tests was measured as the change in the water level in the inner cell through a low capacity differential pressure transducer (LCDPT). In order to separate the routes for measurement and control of the pore air pressure and the pore water pressure, a membrane and a PTFE sheet were used. Figure 2(b) shows the PTFE sheet placed in the top cap to cut off the flow of water. Figure 2(c) shows the membrane filter installed in the lower pedestal to cut off the flow of air. The thin membrane filter with pores of $0.45 \mathrm{~mm}$ has an air entry value of $420 \mathrm{kPa}$. In addition, a solenoid controlled valve to control the exhaust air was also installed in the air drainage line inside the top cap to minimize the air volume (in the air drainage line).

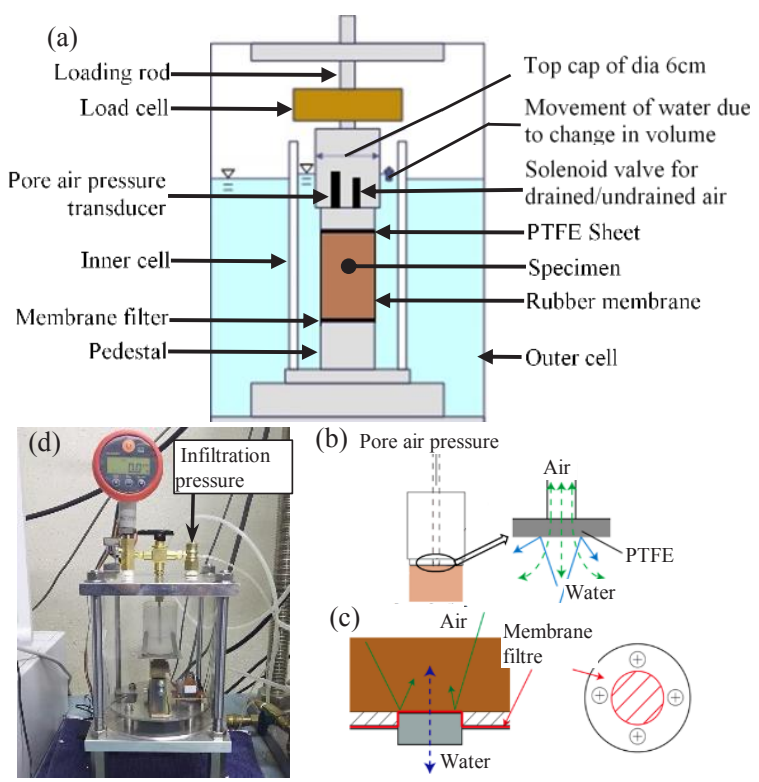

Fig. 2. (a) Schematic figure of the triaxial cell: (b) top cap; (c) bottom pedestal, (d) external load cell

Since this study focuses more on slope failure, it was assumed that the pore air pressure remained atmospheric throughout the test and water infiltration increased only the pore water pressure [7]. Water in an unsaturated soil specimen was injected from the bottom pedestal which was connected to a beaker and the pore water pressure transducer through the water line. The beaker was placed on an external load cell and encased in a pressure chamber as shown in Figure 2(d). The infiltration rate was controlled by regulating the pressure applied on top of the water surface in the beaker [7], [5].

\subsection{Test procedure}

To study the effect of water infiltration on the mechanical behaviour of unsaturated soil two series of tests has been performed in constant matric suction plane. The stress path of the infiltration and drained shear test series is shown in Figure 3. There are two main stages in the infiltration and drained shear tests performed in this study. The first stage of the test is to infiltrate water from the base of the saturated pedestal through high air entry membrane filter into the soil specimen while maintaining 
the constant deviatoric stress $(0 \mathrm{kPa})$ on the specimen $(B \rightarrow D)$. The second stage of the test is to shear the soil specimen under drained conditions with allowing drainage water. After applying the desired infiltration pressure to the chamber, the drainage valve for the pore water pressure was opened while maintaining the constant deviatoric stress $(0 \mathrm{kPa})$ on the specimen. Path $B D$ shows the reduction in matric suction within constant net stress plane which results in wetting of soil specimen, the water infiltration was carried out until no further water was infiltrated into the specimen. Once the water infiltration completed, the soil specimen was sheared in drained conditions by opening drainage valve for the pore water pressure. Path $D E$ shows the increase in deviator stress of soil specimen when the shearing was carried out within constant matric suction plane with the change of mean effective stress. During the infiltration and drained shear test the drainage valve for pore-air remained open.
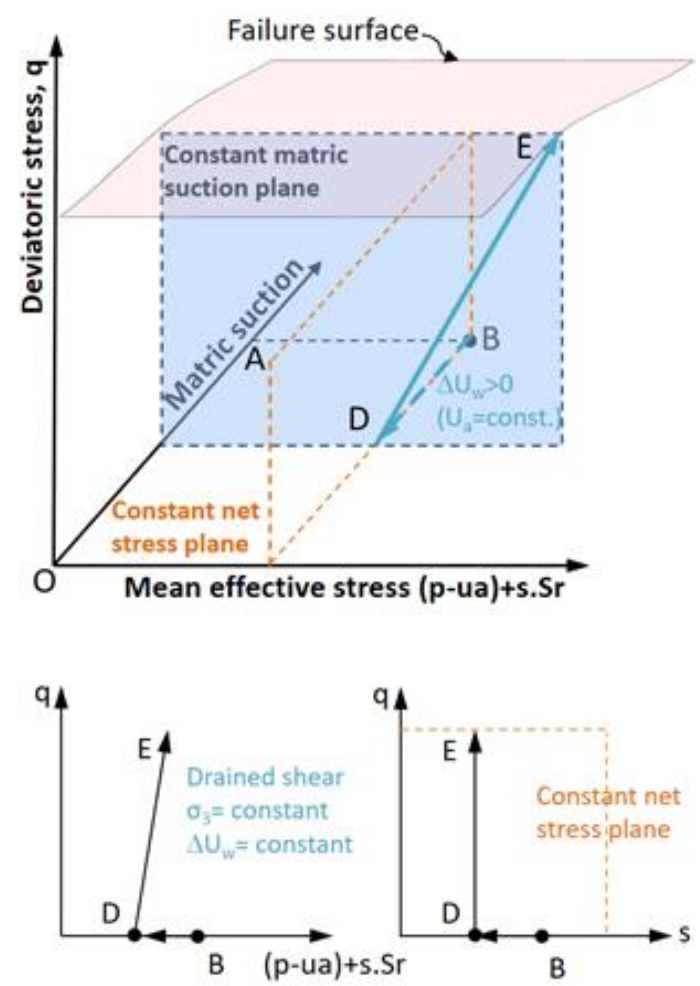

Fig. 3. Stress paths for infiltration and drained shear tests series (Series-I)

The wetting path of the infiltration and constant water content test series is shown in Figure 4. There are two main stages in the infiltration and constant water content tests performed in this study. The first stage of the test is to infiltrate water from the base of the saturated pedestal through high air entry membrane filter into the soil specimen while maintaining the constant deviatoric stress $(0 \mathrm{kPa})$ on the specimen $(B \rightarrow F)$. The second stage of the test is to shear the soil specimen under constant water content conditions without allowing drainage water. After applying the desired infiltration pressure to the chamber, the drainage valve for the pore water pressure was opened while maintaining the zero axial strain on the specimen.
Path $B F$ shows the reduction in matric suction within constant net stress plane which results in wetting of soil specimen, the water infiltration was carried out until no further water was infiltrated into the specimen. Once the water infiltration completed, the soil specimen was sheared in constant water content conditions by closing the drainage valve for the pore water pressure. Path $F G$ shows the increase in deviator stress of soil specimen when the shearing was carried out in constant water conditions within constant matric suction plane with change of mean effective stress. During the shearing, it was observed that the matric suction changed, therefore, the stress path $F G$ moved away from constant matric suction plane. During the infiltration and constant water content test drainage valve for pore-air remained open.
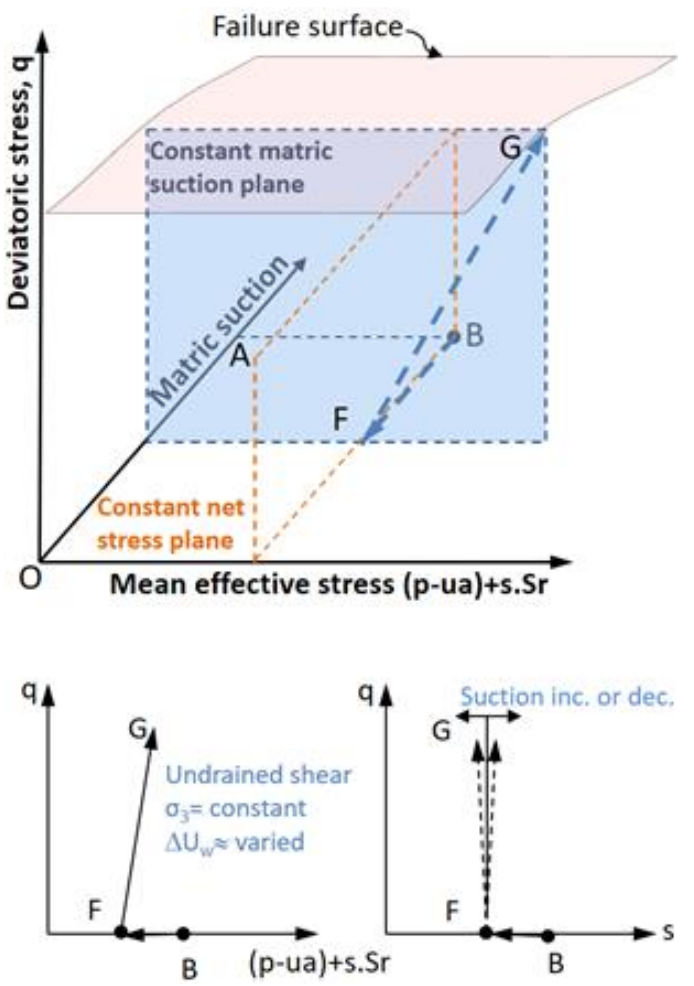

Fig. 4. Stress paths for infiltration and constant water content tests series (Series-II)

\subsection{Test program}

The test program is shown in Table 2. The net confining stress of $100 \& 200 \mathrm{kPa}$ was applied to specimens in test Series-I, specimens in test Series-II were tested at net confining stress of $200 \mathrm{kPa}$ only. After application of net confining stress, the specimens were moved to the shear stage. The shearing was carried out at a strain rate of $0.05 \% / \mathrm{min}$. The tests were performed by increasing pore water pressure to $10 \& 20 \mathrm{kPa}$. Finally, the mechanical behaviour of unsaturated soil under water infiltration was studied and the effect of stress paths on failure state and failure line was also observed. 
Table 2. Stress state of specimens.

\begin{tabular}{|c|c|c|c|c|c|}
\hline Series & Test & $\sigma_{n}$ & $\mathrm{Ua}$ & $\mathrm{Uw}$ & $\mathbf{S}=(\mathbf{U a}-\mathbf{U w})$ \\
\hline \multirow{4}{*}{$\begin{array}{l}\text { Infiltration and } \\
\text { drained shear }\end{array}$} & \multirow{2}{*}{ IDS-s10 } & 100 & \multirow{2}{*}{20} & \multirow{2}{*}{10} & \multirow{2}{*}{10} \\
\hline & & 200 & & & \\
\hline & \multirow{2}{*}{ IDS-s0 } & 100 & \multirow{2}{*}{20} & \multirow{2}{*}{20} & \multirow{2}{*}{$\mathbf{0}$} \\
\hline & & 200 & & & \\
\hline \multirow{2}{*}{$\begin{array}{l}\text { Infiltration and } \\
\text { constant water } \\
\text { content shear }\end{array}$} & ICW-s10 & 200 & 20 & 10 & 10 \\
\hline & ICW-s10 & 200 & 20 & 20 & 0 \\
\hline
\end{tabular}

\section{Experimental results}

Figure 5 shows the results of water infiltration phase which is the same for both test series.

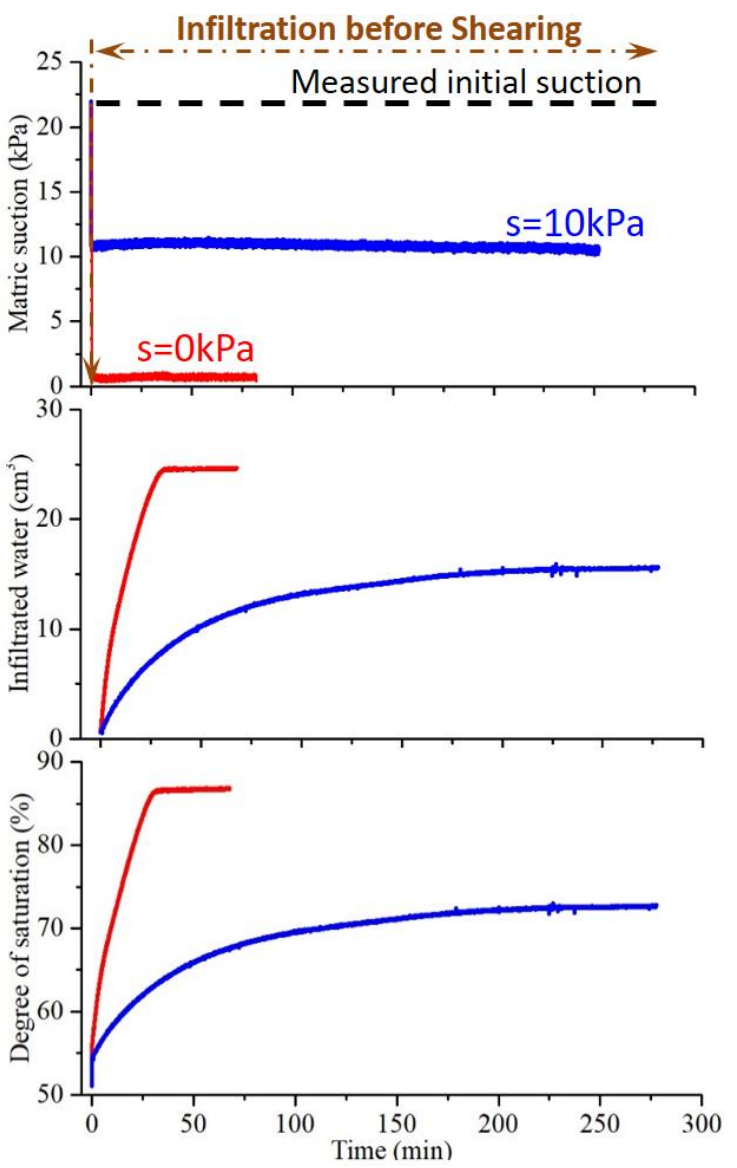

Fig. 5. Effect of decrease in matric suction on water infiltration and degree of saturation during water infiltration process

It can be seen that when matric suction was decreased to $10 \mathrm{kPa}$, water infiltration gets constant in $250-275 \mathrm{~min}$ and $15 \mathrm{~cm}^{3}$ water was infiltrated into the specimen which increased the degree of saturation to $72 \%$. When matric suction was decreased to $0 \mathrm{kPa}$, water rapidly infiltrated into the specimen and get constant after $25 \mathrm{~min}$ and $25 \mathrm{~cm}^{3}$ of water infiltrated into the specimen which increased the degree of saturation to $86 \%$. After completion of the water infiltration process, the specimens were tested in drained $\&$ undrained conditions for pore water pressure in the respective test series.

\subsection{Infiltration and drained shear tests}

Figure 6 shows the behaviour when the soil was sheared in drained conditions for both pore air and pore water at the net confining stress of $200 \mathrm{kPa}$. When the matric suction was decreased to $10 \mathrm{kPa}$ during water infiltration process. The specimen absorbed $15 \mathrm{~cm}^{3}$ of water and degree of saturation increased to $72 \%$, which is not the upper limit of the degree of saturation for the studied soil. The soil further decreased its volume with shearing, as a result void ratio decreased. To maintain matric suction constant, further water was absorbed by the specimen which increased the degree of saturation to $85 \%$ till the end of the shear process. $25 \mathrm{~cm}^{3}$ of water was absorbed by the specimen when the matric suction was decreased to $0 \mathrm{kPa}$ and the degree of saturation increased to $86 \%$, which is the upper limit of the degree of saturation. During the shear process, the soil forced to maintain the maximum degree of saturation. With further shearing, soil decrease its volume and to keep the maximum degree of saturation and constant matric suction the soil drained out the water and $7 \mathrm{~cm}^{3}$ of water was drained out by soil. Finally, it was also observed that the soil specimens sheared at matric suction of $10 \mathrm{kPa}$ and $0 \mathrm{kPa}$ showed same degree of saturation, therefore, their maximum deviatoric stress was also same.

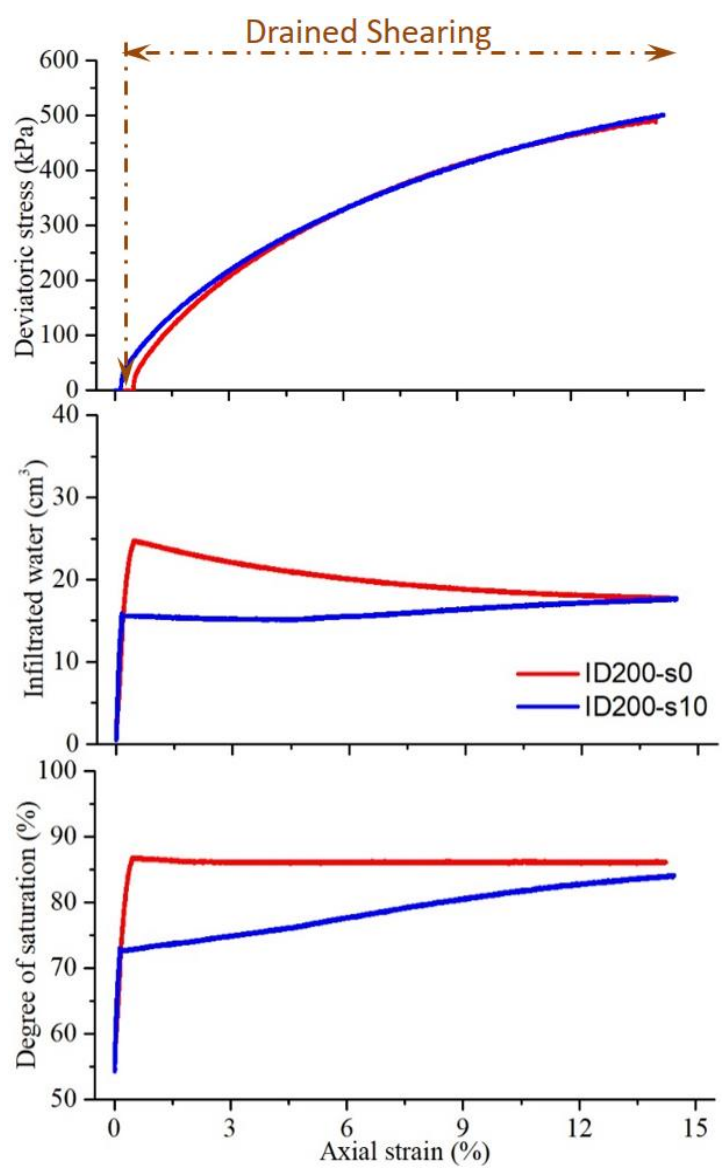

Fig. 6. Soil behaviour during shear in drained conditions (Series-I) 


\subsection{Infiltration and constant water content tests}

Figure 7 shows the behaviour when the soil was sheared in constant water content conditions at the net confining stress of $200 \mathrm{kPa}$. When matric suction was decreased to $10 \mathrm{kPa}$ during water infiltration process. The specimen absorbed $15 \mathrm{~cm}^{3}$ of water and degree of saturation increased to $72 \%$, which is not the upper limit of the degree of saturation. The soil further decreased its volume resulting with shearing, as a result, void ratio decreased. To maintain constant matric suction and the maximum degree of saturation, specimen required to absorb more water.
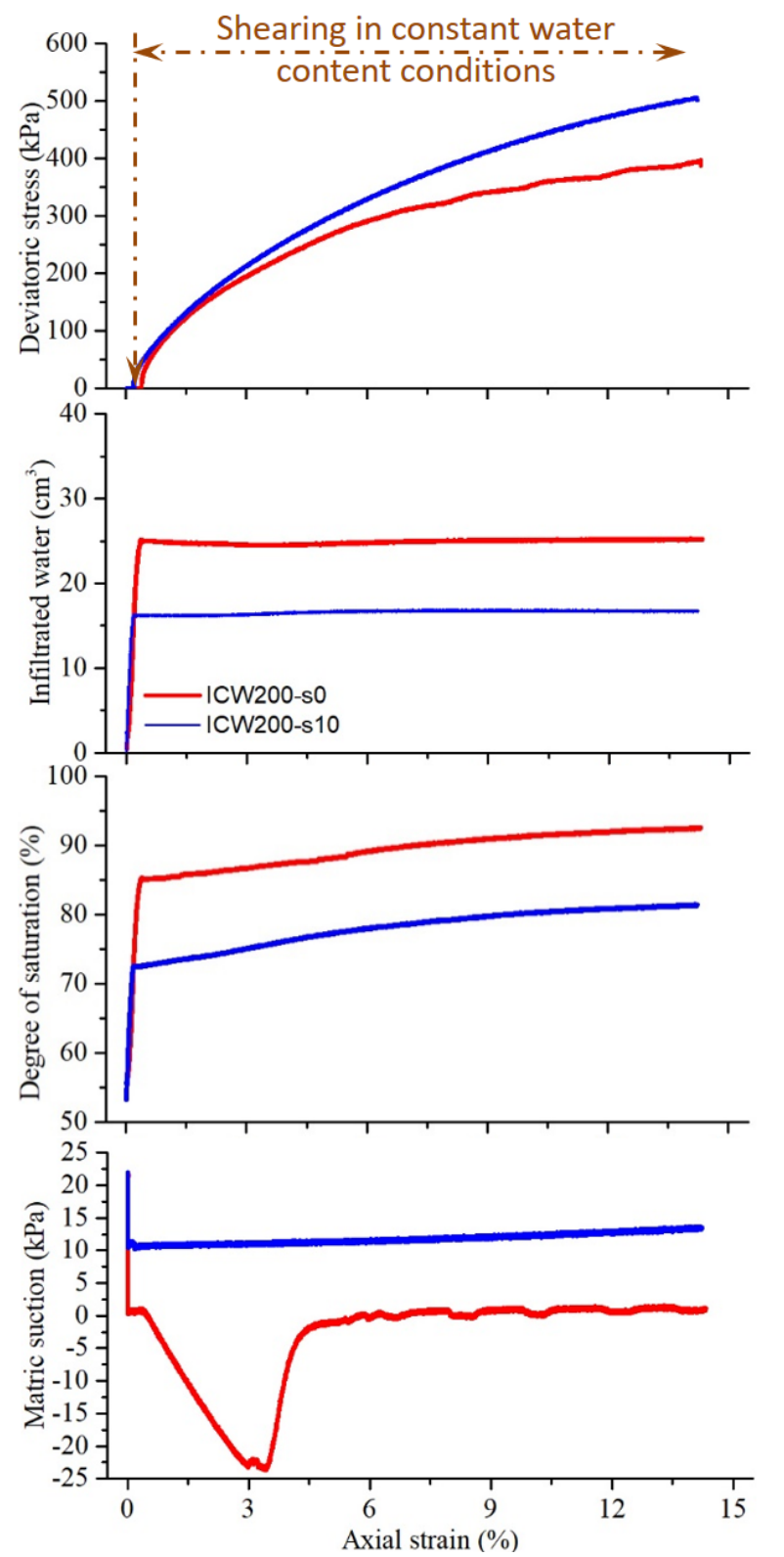

Fig. 7. Soil behaviour during shear in constant water content conditions (Series-II)

As no further water could infiltrate into the specimens, the volume of water remained constant and due to decrease in void ratio degree of saturation increased. The matric suction also changed with degree of saturation.
$25 \mathrm{~cm}^{3}$ of water was absorbed by the specimen at matric suction of $0 \mathrm{kPa}$ and degree of saturation was increased to $85 \%$, which is the upper limit of the degree of saturation. The soil tried to keep degree of saturation to $85 \%$ with further shearing, however, as the shearing was carried out in undrained condition for pore water so no water could drain out of the specimen. The further shearing caused increase in pore water pressure rapidly up to $45 \mathrm{kPa}$ keeping the pore air pressure constant. This also caused dissolution of air and water which resulted in increase in pore air pressure and afterwards both pore water and pore air pressure increase together, maintaining the matric suction to $0 \mathrm{kPa}$. Finally, it was observed that the specimens sheared in undrained conditions for pore water pressure produced different degree of saturation for two values of matric suctions, therefore, they showed different shear strengths.

\subsection{Comparison and Discussion}

The effect of stress paths on failure state in drained and undrained conditions for pore water pressure is shown in Figure 8.
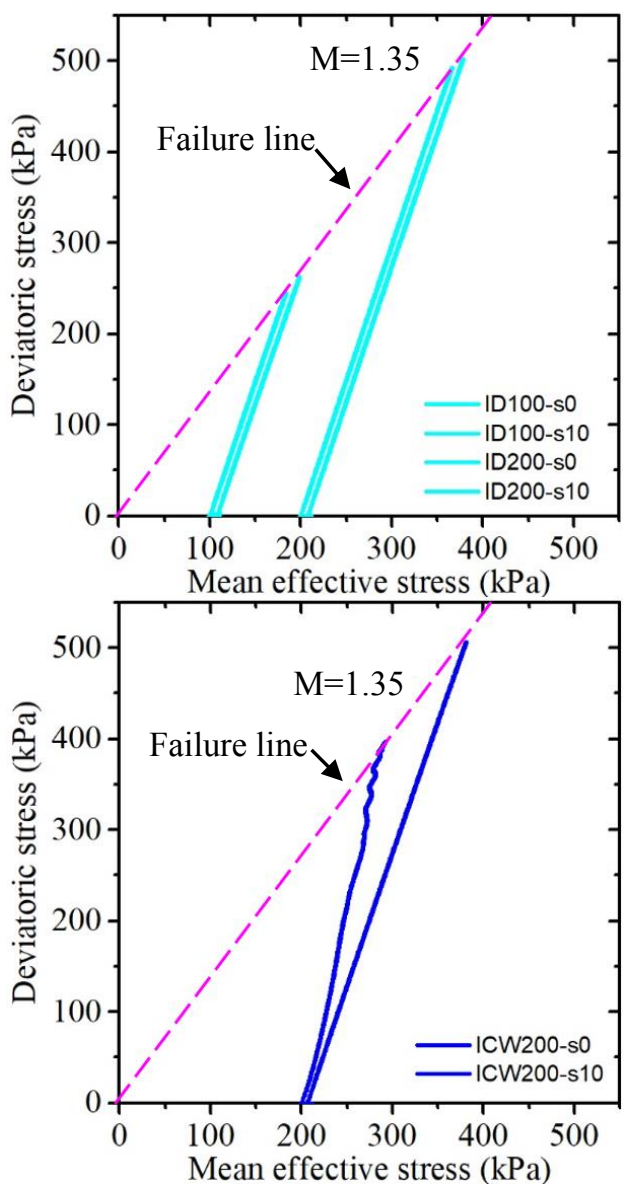

Fig. 8. Effect of stress paths on failure state

In the first case, the matric suction was kept constant as the specimens were sheared in drained conditions. When the specimens reached to the failure it was observed that whether they failed at matric suction of 0 or $10 \mathrm{kPa}$ they showed the same shear strength. Therefore, the final points of the stress paths meet at a straight line with a 
gradient of 1.35 that passes through the origin. When the soil was sheared in undrained conditions the matric suction changed with shearing. Therefore, depending on the matric suction the stress paths changed and the specimens showed different shear strengths. However, the final points fall on the same straight line with a gradient of 1.35 that passes through the origin.

\section{Conclusions}

A series of laboratory elements tests were conducted to study the effect of water infiltration on the mechanical behaviour of unsaturated soil. It was observed that the water infiltration decreased with increase in net confining stress due to the decrease in volume of the specimens and specimens showed same shear strength when failed at matric suction of 0 or $10 \mathrm{kPa}$. It was also observed that the stress path followed in drained and undrained conditions showed movement towards the final state almost the unique failure line. Which means that movement of stress paths was independent of the matric suction, the net confining stress and the shearing conditions for the present experimental study.

\section{References}

1. D.G. Fredlund, H. Rahardjo, Soil mechanics for unsaturated soils. John Wiley and Sons Inc., New York (1993)

2. A.W. Bishop, The measurement of pore pressure in Triaxial test, Proc. of the conf. on pore pressure and suction in soil., 38-46 (1960)

3. D.G. Fredlund, N.R Morgenstern, R.A Widger, Canad. Geotech. J., 313-321 (1978)

4. D. Hormdee, Ochiai, and Yasufuku, Advanced direct shear testing for collapsible soils with water content and matric suction measurement, Proc., of the Intl. symp. on adv. exp. unsat. soil mech., 177-184 (2005)

5. A.M. Rasool, J. Kuwano, and S. Tachibana, Behavior of compacted unsaturated soil in isotropic compression, cyclic and monotonic shear loading sequences in undrained condition, Proc. of $6^{\text {th }}$ Intl. symp. on def. charac. of geomat., 267-274 (2015)

6. F. Melinda, H. Rahardjo, K.K Han, E.C Leong, J. of Geot. and Geoenvn. Engn., 130, 8 (2004)

7. K. Farooq, R. Orense, I. Towhata, Soils and Found., 44, 2 (2004) 